\title{
Environmental citizenship behavior and sustainability apps: an empirical investigation
}

\author{
Mario D'Arco
}

Department of Business Science, Management and Innovation Systems (DISA-MIS), University of Salerno, Fisciano (SA), Italy, and

Vittoria Marino

Department of Law, Economics, Management and Quantitative Methods (DEMM), University of Sannio, Benevento, Italy

Environmental citizenship behavior

Received 15 July 2021 Revised 4 October 2021 22 November 2021 Accepted 17 December 2021

\begin{abstract}
Purpose - This study aims to investigate the moderating effect of sustainability app on environmental citizenship behavior on the basis of norm-activation model.

Design/methodology/approach - A questionnaire survey, which comprises five variables (i.e. awareness of consequences, ascription of responsibility, personal norms, environmental citizenship behavior in a private sphere and environmental citizenship behavior in a public sphere) measured through 16 items, was conducted in the USA by using Amazon Mechanical Turk. With 549 valid respondents' answers in hand, the collected data were analyzed applying a multi-group structural equation modelling technique with IBM SPSS AMOS 23 software program.

Findings - The results revealed that there is a positive and significant relationship between awareness of consequences, ascription of responsibility, personal norms and environmental citizenship behavior in both private and public sphere. Furthermore, this study attested that sustainability apps utilization has a moderating effect on the predictors of environmental citizenship behaviors.

Originality/value - Past studies have seldom examined the contribution of mobile apps to environmental sustainability. This paper enriches the extant academic literature in the field of technology for behavior change, and bears significant implications on how sustainability apps can be adopted by governments, policymakers, organizations and teacher educators to engage people and stimulate environmental citizenship behaviors.
\end{abstract}

Keywords Mobile application, Norm-activation model, Private-sphere environmentalism, Public-sphere Environmentalism, Pro-environmental behavior

Paper type Research paper

\section{Introduction}

Sustainability, defined as "the development that meets the needs of the present without compromising the ability of future generations to meet their own needs"

(c) Mario D'Arco and Vittoria Marino. Published by Emerald Publishing Limited. This article is published under the Creative Commons Attribution (CC BY 4.0) licence. Anyone may reproduce, distribute, translate and create derivative works of this article (for both commercial \& noncommercial purposes), subject to full attribution to the original publication and authors. The full terms of this licence may be seen at http://creativecommons.org/licences/by/4.0/legalcode

Declaration of interests: The authors declare that they have no known competing financial interests or personal relationships that could have appeared to influence the work reported in this paper.

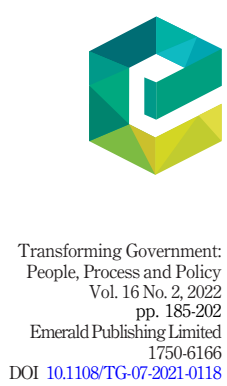


TG

16,2

186
(United Nations, 1987, p. 37), is a recurrent theme in the international policy agenda since the United Nations Conference on Environment and Development in Rio de Janeiro in 1992 (Cohen, 2020).

During the following decades, politicians, governments, not-for-profit organizations, activists groups and green entrepreneurs have taken several initiatives to spread information about the ecological crisis caused by unsustainable human practices of production and consumption (Barry, 2006; Stern, 2011; Ockwell et al., 2009; Yang, 2020) and encourage environmental citizenship behavior.

The concept of environmental citizenship is not easy to define because it overlaps with more established constructs such as environmental education, environmental behavior, environmental attitudes, environmental literacy, awareness, sustainability and sustainability education (Hadjichambis and Reis, 2020). Furthermore, this concept is studied by different disciplines due to its political, economic and societal dimensions (Georgiou et al., 2021). This explain why, in the extant literature, the concept of environmental citizenship is found under different labels, such as ecological citizenship (Jagers and Matti, 2010), green citizenship (Gabrielson, 2008) and sustainability citizenship (Barry, 2006).

According to some studies (Bell, 2005; Dobson, 2010), environmental citizenship is a distinct form of citizenship with specific characteristics. Given that the essence of citizenship consists in possessing a formal membership status in a political and legal entity in which each individual has specific rights and obligations (Bellamy, 2014), it follows that environmental citizenship refers to the obligation of each citizen belonging to that community to preserve the surrounding environment. Specifically, as highlighted by Dobson (2010, p. 6), environmental citizenship behavior can be defined as a "pro-environmental behavior, in public and private, driven by a belief in fairness of the distribution of environmental goods, in participation, and in the co-creation of sustainability policy."

As supported by the above-mentioned definition, environmental citizens can undertake both individual and collective actions to protect the environment. In addition, these actions can be performed by individuals either in private or in public settings. Examples of environmental citizens actions classified into different quadrants by following the dichotomies collective/individual actions and private/personal sphere are depicted in Figure 1 adapted from Hadjichambis and Paraskeva-Hadjichambi (2020).

Environmental citizenship requires some important prerequisites such as skills, duties, rights, awareness and responsibility to both motivate and enable environmentally conscious actions. Government intervention, such as policies, laws, environmental public communications and involvement of citizens, as well as environmental education, traditional media, environmental content shared on social media and advertising campaigns can play an important part in promoting environmental citizenship behavior (Bauer et al., 2020; de Vries, 2020; Georgiou et al., 2021). Unfortunately, although most people are aware of phenomena related to continued unsustainable human activities, such as climate change, loss of biodiversity, ice melt, plastic pollution and ocean pollution, only few of them are willing to embrace the global community goal of "saving the planet" (de Guttry et al., 2019; Huang, 2016; Moussaoui and Desrichard, 2016; Wang et al., 2018).

People resistance towards pro-environmental behavior, namely a "behavior that consciously seeks to minimize the negative impact of one's actions on the natural and built world" (Kollmuss and Agyeman, 2002, p. 240), might arise due to psychological distance of environmental threats (Gifford, 2011; Milfont, 2010) or habit (Verplanken and Roy, 2016). Furthermore, individuals reject "what is perceived as a power, a pressure, an influence, or any attempt to act upon one's conduct” (Roux and Izberk-Bilgin, 2018, p. 295). This means that governments and marketing practitioners should avoid messages that could be 


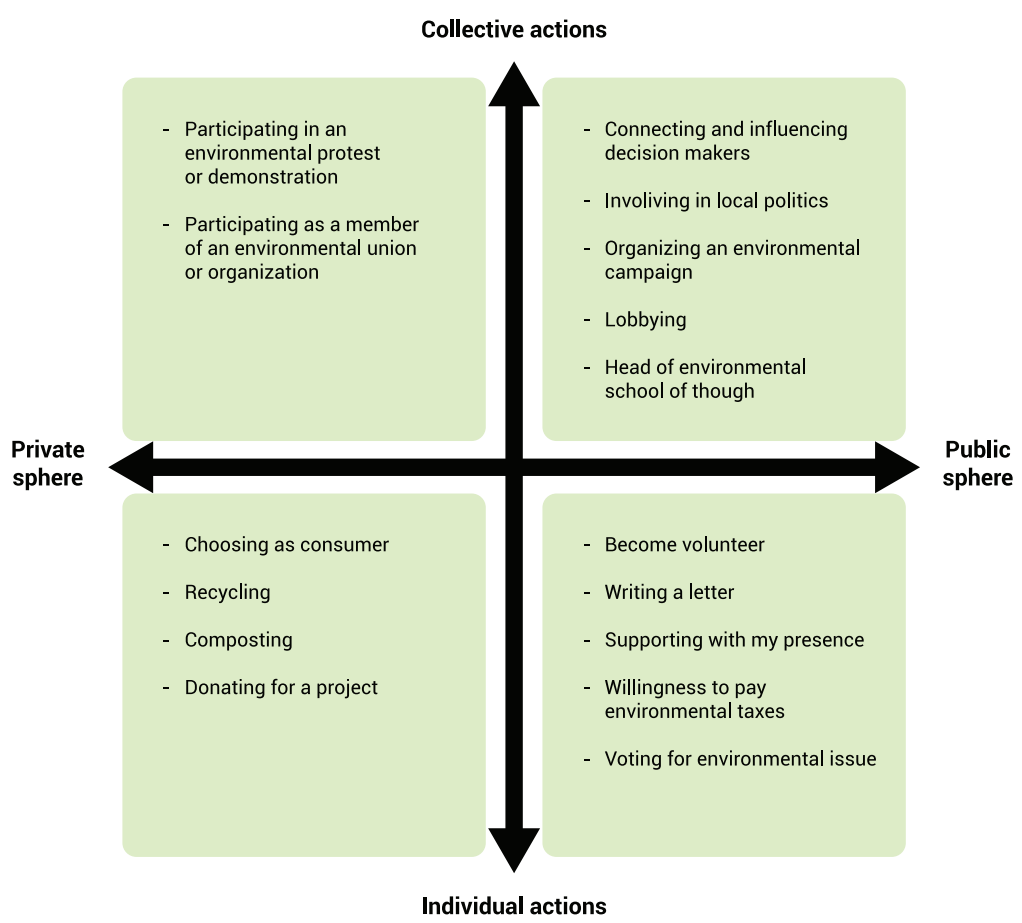

Source: Adapted from Hadjichambis and Paraskeva-Hadjichambi, 2020
Environmental citizenship behavior

187

Figure 1.

Examples of environmental citizenship actions in a for-quadrant representation

perceived as manipulative, such advertising campaign that makes individuals feel fearful, obligated or guilty. In fact, empirical studies demonstrate that alarmistic and fear messages are often not effective in creating a behavior change (de Vries, 2020).

In search of innovative and interactive ways to inspire and motivate citizens to be more sustainable in their everyday life, the use of mobile applications (apps) has gained the attention of scholars and practitioners in recent years (Brauer et al., 2016; Nghiem and Carrasco, 2016; Ouariachi et al., 2020). The relationship between technologies and human actors can give birth to new processes, values, and social rules (Troisi et al., 2018; Troisi et al., 2021). Information and communication technologies (ICTs) also contributes to the developments and advances in the practice of teaching and learning worldwide (Visvizi et al., 2018a). Specifically, the utilization of sustainability apps presents huge potential to enhance awareness about sustainability (Yanamandra and Ramesh, 2019) and induce change in behavior without adopting hard paternalism forms, that is, actions that interfere with individuals' liberty or autonomy (Diefenbach et al., 2016).

An analysis of extant literature revealed that researches on sustainability apps have prevalently focused on their classification (Brauer et al., 2016), design characteristics (Mulcahy et al., 2020), adoption intention (Aguiar-Castillo et al., 2018; Whittaker et al., 2021), and educational function (Abner and Baytar, 2019; Montiel et al., 2017). Simultaneously, there is a paucity of empirical evidence on how such technologies might intervene in the process leading to environmental citizenship behavior. 
TG

16,2
For that reason, the purpose of the current study consists of filling this knowledge gap by conducting a multi-group analysis to evaluate the moderating effect of the use of sustainability app on environmental citizenship behavior.

The remainder of the paper is organized as follows. In Section 2, the background is presented and the research hypotheses are developed. The measurement instrument and data collection procedure are reported in Section 3. Statistical analysis methods and results are introduced in Section 4. Subsequently, in Sections 5, we report a discussion of the findings and implications for theory and practice. In Section 6, conclusions, research limitations and future research directions are presented.

\section{Theoretical background and hypotheses}

\subsection{Norm activation model}

According to Smederevac-Lalic et al. (2020), environmental citizenship behaviors have a normdriven nature. Therefore, we adopted the norm-activation model developed by Schwartz (1977) as our basic model to explore environmental citizenship behavior. Furthermore, we evaluated the moderating effect of a specific contextual variable, namely, sustainability app usage, on the relationships between the constructs that characterize the norm-activation model.

The norm-activation model is grounded on the assumption that an individual is disposed to sacrifice her/his own self-interest for the collective benefits of others. As highlighted by Schwartz (1977), this form of altruistic behaviors is influenced by personal norms, awareness of consequences and ascription of responsibility.

In the environmental psychology literature, personal norms are defined as "moral obligations to perform or refrain from specific actions" (Schwartz and Howard, 1981, p. 191). Personal norms are cognitive structures varying from subject to subject constructed on the basis of inputs from the external situation and internal reasons in agreement with values, beliefs, conceptions of right and wrong, good or bad (Schwartz, 1977; Thøgersen, 2006).

Awareness of consequences refers to the individual's disposition to become aware of the potential consequences of her/his behavior for the welfare of others or for other things (Schwartz, 1977). If an individual is aware of the consequences that her/his actions may have on others, then norms guiding how she/he should or should not behave are activated and feelings of moral obligation are induced (Kaiser and Shimoda, 1999). For example, if a person is aware of the effects of plastic pollution on marine life, he/she may be likely to engage in recycling of plastic waste.

Ascription of responsibility concerns with the individual tendency to see "the self as responsible for events initially" (Schwartz, 1977, p. 230). People's actions can have positive and negative consequences on the other people, the other species and the environmental wellbeing. Therefore, as highlighted by Stern et al. (1999, p. 83), ascription of responsibility is "the belief or denial that one's own actions have contributed to or could alleviate those consequences". For example, an individual tends to view energy saving in the workplace as her/his own responsibility rather than of her/his organization.

Extant research has applied the norm-activation model in various contexts concerning pro-social and pro-environmental behavior, such as environmental complaint behavior (Zhang et al., 2018), electric vehicle adoption (Bobeth and Kastner, 2020), electricity saving behavior (Zhang et al., 2013), reduce clothing consumption (Joanes, 2019; Polese et al., 2019) and volunteer tourism traveler behavior (Meng et al., 2020).

\subsection{The moderating role of sustainability apps}

ICTs are generally a viable way to influence individuals' behavior (Brauer et al., 2016). Example from the health, education and public service domain show that the utilization 
of apps can serve as successful interventions (Carlo Bertot et al., 2012; Eid et al., 2020; Hirsh-Pasek et al., 2015; Oni et al., 2016; Pai and Alathur, 2019; Reddick and Zheng, 2017). Apps are dedicated software applications that run on portable devices such as smartphones and tablets (Gokgoz et al., 2021). App stores like those from Apple and Google offer the possibility to download different types and categories of apps, for example, social networking apps, online shopping apps, gaming apps, apps for food lovers, mobile wallet apps, health apps and education apps (Mehra et al., 2020). Recently, apps have also proven to be helpful achieving sustainability-related goals (Brauer et al., 2016). Some examples concerning the domain and functions of the most popular sustainability apps are illustrated in Table 1.

Since we are dealing with a young product category, there is little research on sustainability apps. Most studies in the field mainly focused on how technology could be designed to actively influence and change human behavior. One design principle is the "aesthetic of friction" (Laschke et al., 2015), that is, break up the routine to inspire reflection (Diefenbach et al., 2016). For example, a data-driven app, such as a carbon footprint calculator, could make us think about how much our lifestyle is unsustainable and thus render the choice between taking the car or the bike more deliberate. In their study, Brauer et al. (2016) highlighted that sustainability apps could be implemented with one or more of the following functions: educate, gamify, informate, transformate and collaborate.

\begin{tabular}{|c|c|c|}
\hline App name & Domain & Description \\
\hline Good on You & Sustainable ethical fashion & $\begin{array}{l}\text { The app provides ratings, information, offers and } \\
\text { news about ethical and sustainable fashion }\end{array}$ \\
\hline JouleBug & Sustainable lifestyle & $\begin{array}{l}\text { The app uses a gamification model with points } \\
\text { awarded for completing sustainable actions }\end{array}$ \\
\hline Oroeco & Pollution & $\begin{array}{l}\text { The app automatically tracks the user's climate } \\
\text { impacts with the world's best carbon footprint } \\
\text { calculator. The user receives information, points and } \\
\text { competes with the other members of the community }\end{array}$ \\
\hline AWorld & Education & $\begin{array}{l}\text { The app, which was created in support of ActNow } \\
\text { United Nations campaign for individual action on } \\
\text { climate change and sustainability, employs } \\
\text { gamification, challenges and engaging contents to } \\
\text { guide users towards living sustainably }\end{array}$ \\
\hline GoodGuide & Ethical consumerism & $\begin{array}{l}\text { The app helps users to find safe, healthy and } \\
\text { sustainable products while they are shopping }\end{array}$ \\
\hline iRecycle & Recycling & $\begin{array}{l}\text { The app gives information to handle any recycling } \\
\text { challenge }\end{array}$ \\
\hline HappyCow & Vegan food locator & $\begin{array}{l}\text { The app helps users to find vegan-options at } \\
140,000+\text { restaurants, cafes and grocery stores in } \\
180+\text { countries }\end{array}$ \\
\hline My Plastic Diary app & Reducing plastic pollution & $\begin{array}{l}\text { The app helps users to track and reduce their plastic } \\
\text { footprint. Log all plastic items you buy, set goals, } \\
\text { receive virtual awards and share your progress on } \\
\text { social media to inspire others }\end{array}$ \\
\hline Buycott app & Consumer activism & $\begin{array}{l}\text { The app gives real-time transparency information } \\
\text { about products by reading the Universal Product } \\
\text { Codes barcode. The app helps users to boycott bad } \\
\text { products and find sustainable alternatives }\end{array}$ \\
\hline Olio & Reducing food waste & $\begin{array}{l}\text { The app connects neighbors with each other and } \\
\text { local shops so that surplus food can be shared }\end{array}$ \\
\hline
\end{tabular}

Environmental citizenship behavior

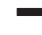


TG

16,2

According to Georges et al. (2015), the main persuasive techniques used by app developers to help people to live more sustainably are eco-feedback, reminder, reward, self-monitoring tool, suggestion and trigger. Several studies (Douglas and Brauer, 2021; Johnson et al., 2017; Mulcahy et al., 2020) also suggest that gamification helps creating a condition favorable for the pro-environmental education of the individual. Apps help reducing the ignorance barrier and contribute to the habit formation. Specifically, gamified apps try to deal with the problem of personal motivation by adopting extrinsic motivation such as points, levels, discounts and badge.

Based on the discussion above, which prevalently focuses on how apps can assist behavior change, we hypothesize that sustainability apps can help strengthen the relationship between personal norms, environmental awareness and responsibility, as well as motivate environmental citizenship behavior in both private and public settings. Specifically, we derived the following hypotheses:

H1. The correlation between awareness of consequences and ascription of responsibility is stronger for individuals who use sustainability apps.

H2. The correlation between ascription of responsibility and personal norms is stronger for individuals who use sustainability apps.

H3. The correlation between personal norms and environmental citizenship behavior in private-sphere is stronger for individuals who use sustainability apps.

H4. The correlation between personal norms and environmental citizenship behavior in public-sphere is stronger for individuals who use sustainability apps.

The conceptual model underlying this study is presented in Figure 2.

\section{Methods}

\subsection{Measurements and instrument development}

This research adopted a self-administered questionnaire survey technique. The questionnaire (Table 2) was designed to explore five different variables and comprised 16 items measured on a seven-point Likert scale $(1=$ Strongly disagree to $7=$ Strongly agree).

The questionnaire started with a filter question to identify two different subsets of survey respondents, namely, individuals who use sustainability apps and individuals who do not use sustainability apps. Individuals who answered to use sustainability apps had also to specify the name of the app and the frequency of usage before to jump to the common section containing a battery of questions concerning the measurement of the environmental citizenship behavior. Questions regarding respondents' demographic information were included at the end of the survey.

The items measuring awareness of consequences, ascription of responsibility and personal norms were adapted from Onwezen et al. (2013). The environmental citizenship behavior was measured on two dimensions, namely, the private-sphere and the publicsphere. The items were generated by taking in consideration the examples of environmental citizenship behavior provided by extant literature, such as Hadjichambis and ParaskevaHadjichambi (2020).

\subsection{Data collection}

Amazon Mechanical-Turk (MTurk) was used to recruit participants for our research (Shank, 2016). The survey was lunched June 16, 2021. In the panel option, we specified the target of our online survey. In addition, we selected 550 as number of MTurk 


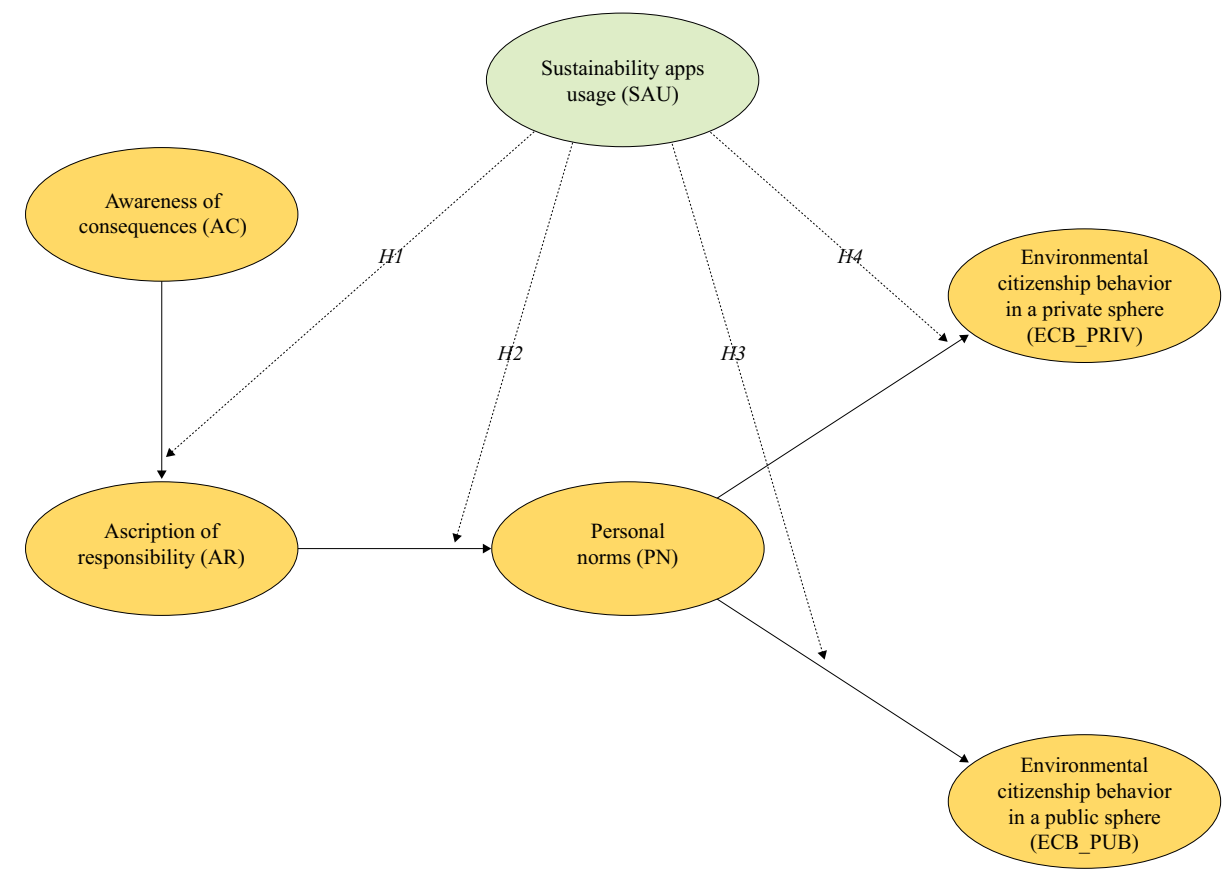

Environmental citizenship behavior

Source: Our elaboration

Figure 2. Conceptual model

workers. In a few days, 550 questionnaires from respondents living in the USA were collected. One questionnaire was excluded from the analysis because the name of the app was not inserted. Therefore, the final dataset comprised 549 valid answers. As presented in Table 3, 53.6\% of the participants are female. Most participants are between $18-24(50.1 \%)$ and $25-34$ years old (27.3\%). Participants who received higher education accounted for $81.3 \%$. Of the 549 respondents, the $48 \%$ of participants use sustainability apps.

\section{Data analysis and results}

This research employed IBM SPSS Statistics 25 and IBM SPSS AMOS 23 to perform the data analysis. First, we conducted a confirmative factor analysis (CFA) and inspected the reliability and validity of the measurement model. Second, to evaluate the moderating effect of sustainability app utilization on each relationship between environmental citizenship behavior and its predictors we performed a multi-group analysis via partial least squares structural equations modeling.

\subsection{Reliability and validity analysis}

Prior to assess the reliability and validity of the measurement model, with the help of IBM SPSS Statistics 25 we conducted the descriptive statistics analysis and the normality test. As shown in Table 4, skewness and kurtosis value for each item was below \pm 3 and \pm 10 respectively (Kline, 2011); hence, data were normally distributed. 
Construct Items

Norm-activation model

Awareness of $\quad \mathrm{AC1}$

consequences (AC) $\quad \mathrm{AC} 2$

AC3

$\mathrm{AC4}$

192

Ascription of

AR1

responsibility (AR) AR2

Personal norm (PN) PN1

PN2

PN3

PN4

The effects of pollution on public health are worse than we realize

Pollution generated in one country harms people all over the world

The balance in nature is delicate and easily upset

Over the next several decades, thousands of species will become

extinct

Every citizen must take responsibility for the environment

I feel partly responsible for the environmental problems on our

planet

I feel a moral obligation to protect the environment

I feel that I should protect the environment

I feel it is important that people in general protect the environment

Because of my own values/principles, I feel an obligation to behave

in an environmentally-friendly way

Environmental citizenship behavior (ECB)

Private-sphere ECB_PRI1 At home, I reduce the amount of energy I use

(ECB_PRI)

ECB_PRI2 I recycle cans, bottles and papers

Public-sphere

(ECB_PUB)

ECB_PRI3 I buy products that are friendly to the environment

ECB_PUB1 I keep the surrounding environment clean

ECB_PUB2 I vote for a candidate or referendum that supports environmental protection

Table 2.

Constructs' scale

ECB_PUB3 I encourage people around me joining and donating to environmental organizations

We also estimated the mean of each items of the measurement model and compared the results between the two different groups. As illustrated in Figure 3, with the exception of few items (i.e. AC_2, ECBPUB_2 and ECBPUB_3), the level of agreement of respondents who use sustainability apps is higher than that of respondents who do not use sustainability apps.

The measurement model was conducted using confirmatory factor analysis (CFA). IBM SPSS AMOS 23 was used to perform the CFA. The results of the CFA revealed a good fit. Specifically, the Root mean square error of approximation (RMSEA) $=0.048$, the Bentler's comparative fit index $(\mathrm{CFI})=0.977$, the Tucker-Lewis index (TLI) $=0.970$ and the normed fit index $(\mathrm{NFI})=0.959$. In addition, the chi-squared test denoted good model fit too $(\mathrm{CMIN} / \mathrm{df}=210.675 / 94=2.241, p<0.001)$, the value, in fact, was less than 3.0 (Hair et al., 2010). To examine the reliability of the measurement model, we used Cronbach's alpha values and composite reliability (CR) values respectively. As depicted in Table 5, Cronbach's $\alpha$ value ranged from 0.749 to 0.938 ; hence met the cut-off value of $\geq 0.70$ (Hair et al., 2010). CR ranged from 0.756 to 0.939 that meets the suggested criterion of $\geq 0.60$ (Hair et al., 2010). Therefore, the results suggest that the reliability is acceptable. The validity of the measurement model was estimated by examining both convergent validity and discriminant validity (Hair et al., 2010). Average variance extracted (AVE) was used to measure convergent validity. As shown in the Table 5, all the AVE of each construct, which ranged from 0.548 to 0.837 , also met the suggested criterion of $\geq 0.50$ (Hair et al., 2010). Thus, the convergent validity is acceptable. Finally, to test the discriminant validity, we compared the square root of the average variance extracted $(\sqrt{A V E})$ with the correlations among the five constructs. The $\sqrt{A V E}$ of each construct was higher than the off-diagonal 


\begin{tabular}{|c|c|c|c|}
\hline Details of respondents $(\mathrm{N}=549)$ & $\mathrm{n}$ & $(\%)$ & Environmental \\
\hline $\begin{array}{l}\text { Gender } \\
\text { Female } \\
\text { Male } \\
18-24\end{array}$ & $\begin{array}{l}294 \\
255 \\
275\end{array}$ & $\begin{array}{l}53.6 \\
46.4 \\
50.1\end{array}$ & behavior \\
\hline $\begin{array}{l}\text { Age } \\
25-34 \\
35-44\end{array}$ & $\begin{array}{l}150 \\
124\end{array}$ & $\begin{array}{l}27.3 \\
22.6\end{array}$ & 193 \\
\hline $\begin{array}{l}\text { Education level } \\
\text { High school graduate or equivalent } \\
\text { Bachelor degree } \\
\text { Master's degree }\end{array}$ & $\begin{array}{r}103 \\
399 \\
47\end{array}$ & $\begin{array}{r}18.8 \\
72.7 \\
8.6\end{array}$ & \\
\hline $\begin{array}{l}\text { Occupation } \\
\text { Studying } \\
\text { Employed }\end{array}$ & $\begin{array}{r}37 \\
388\end{array}$ & $\begin{array}{r}6.7 \\
70.7\end{array}$ & \\
\hline $\begin{array}{l}\text { Sustainability app utilization } \\
\text { Self-employed/Freelance } \\
\text { Yes } \\
\text { No }\end{array}$ & $\begin{array}{l}124 \\
261 \\
288\end{array}$ & $\begin{array}{l}22.6 \\
48 \\
52\end{array}$ & \\
\hline $\begin{array}{l}\text { Frequency of usage (app) } \\
\text { A couple of times a month } \\
\text { A few times per week } \\
\text { At least once a day } \\
\text { A few times everyday }\end{array}$ & $\begin{array}{r}13 \\
82 \\
135 \\
31\end{array}$ & $\begin{array}{r}5 \\
31 \\
52 \\
12\end{array}$ & \\
\hline $\begin{array}{l}\text { Top } 5 \text { sustainability app } \\
\text { JouleBug } \\
\text { Good on You } \\
\text { Buycott } \\
\text { Olio } \\
\text { GoodGuide }\end{array}$ & $\begin{array}{l}46 \\
44 \\
35 \\
31 \\
16\end{array}$ & $\begin{array}{l}8.4 \\
8.0\end{array}$ & $\begin{array}{r}\text { Table } 3 . \\
\text { Demographic profile } \\
\text { of the respondents }\end{array}$ \\
\hline
\end{tabular}

\begin{tabular}{|c|c|c|c|c|c|c|c|}
\hline Construct & Items & $\lambda$ & Mean & SD & Skewness & Kurtosis & \\
\hline \multirow[t]{4}{*}{ Awareness of consequences (AC) } & $\mathrm{AC} 1$ & 0.643 & 6.56 & 0.736 & -1.640 & 2.040 & \\
\hline & $\mathrm{AC} 2$ & 0.745 & 6.31 & 0.951 & -1.134 & 0.055 & \\
\hline & $\mathrm{AC} 3$ & 0.737 & 6.23 & 0.901 & -0.841 & -0.412 & \\
\hline & $\mathrm{AC} 4$ & 0.826 & 6.31 & 0.877 & -0.995 & -0.239 & \\
\hline \multirow{2}{*}{ Ascription of responsibility (AR) } & AR1 & 0.705 & 6.50 & 0.836 & -1.897 & 4.346 & \\
\hline & AR2 & 0.850 & 6.40 & 0.912 & -1.341 & 0.622 & \\
\hline \multirow[t]{4}{*}{ Personal norm (PN) } & PN1 & 0.816 & 6.09 & 0.977 & -0.686 & -0.716 & \\
\hline & PN2 & 0.835 & 6.31 & 0.762 & -0.579 & -1.063 & \\
\hline & PN3 & 0.753 & 6.26 & 0.779 & -0.498 & -1.189 & \\
\hline & PN4 & 0.671 & 6.34 & 0.748 & -0.634 & -0.958 & \\
\hline ECB Private-sphere & ECB_PRI1 & 0.938 & 5.85 & 1.374 & -1.270 & 1.363 & \\
\hline \multirow[t]{2}{*}{ (ECB_PRI) } & ECB_PRI2 & 0.936 & 5.95 & 1.332 & -1.446 & 1.990 & \\
\hline & ECB_PRI3 & 0.869 & 5.98 & 1.385 & -1.564 & 2.282 & \\
\hline ECB Public-sphere & ECB_PUB1 & 0.840 & 6.68 & 0.598 & -1.843 & 2.922 & Toble 4 \\
\hline \multirow[t]{2}{*}{ (ECB_PUB) } & ECB_PUB2 & 0.821 & 6.58 & 0.694 & -1.517 & 1.788 & $\begin{aligned} \text { Table } 4 . & \end{aligned}$ \\
\hline & ECB_PUB3 & 0.687 & 6.52 & 0.812 & -1.946 & 4.874 & $\begin{array}{l}\text { Descriptive statistics } \\
\text { analysis and the }\end{array}$ \\
\hline \multicolumn{7}{|c|}{ Notes: $\lambda=$ Factor loading, $\mathrm{SD}=$ Standard deviation. } & normality test \\
\hline
\end{tabular}



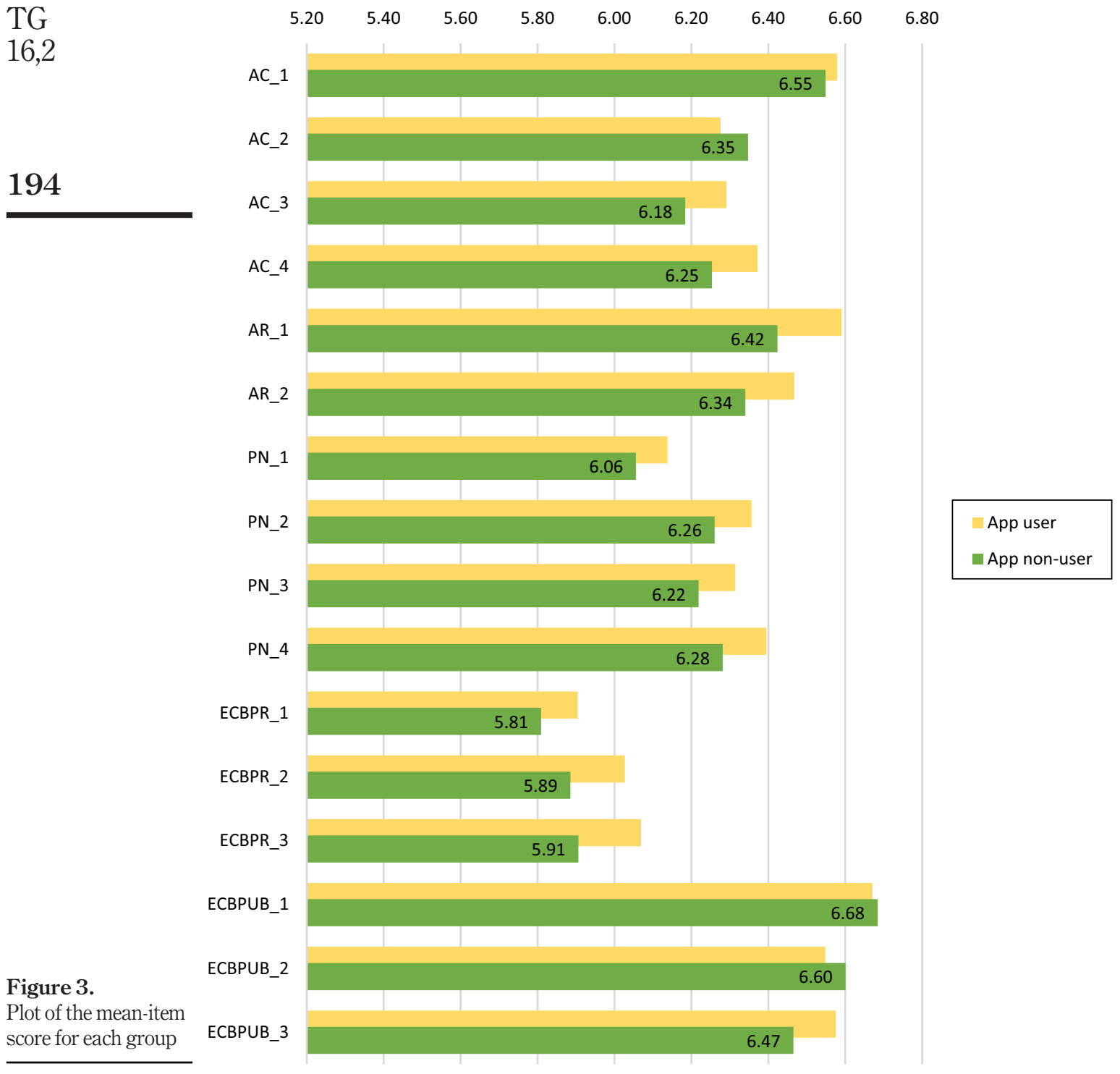

Figure 3.

Plot of the mean-item score for each group

ECBPUB_3

correlation values. Therefore, according to Fornell-Larcker criterion analysis, discriminant validity was supported (Fornell and Larcker, 1981).

\subsection{Multi-group analysis}

A multi-group analysis using IBM SPSS AMOS 23 was conducted to examine the moderating effect of sustainability app utilization. Research participants were divided in 
two groups, those who use sustainability app in their everyday life (Group $1 ; n=261$ ), and those who do not use sustainability apps (Group 2; $\mathrm{n}=288$ ).

Following Byrne (2004), to determine whether the structural model of the two groups are statistically different from each other, we performed a multi-group invariance testing. The $p$-value of the chi-square difference test between the unconstrained $\left(X^{2}=417.725\right.$, $\mathrm{df}=$ $80, p<0.001)$ and the constrained $\left(X^{2}=449.018, \mathrm{df}=65, p<0.001\right)$ subset models is significant $\left(\Delta X^{2}=31.293, \Delta \mathrm{df}=15, p=0.008\right)$. This means that the hypothesis of invariant factor variances must be rejected; hence, the model differs across the groups.

In both models, the relationships between variables are all positive and statistically significant. However, the model regarding the individuals who use sustainability apps presents larger standardized path coefficients $(\beta)$ and coefficient of determination $\left(R^{2}\right) . H 1$, $H 2, H 3$ and $H 4$ are supported. Therefore, sustainability apps utilization exerts a moderating effect on the relationship between awareness of consequences, ascription of responsibility, personal norms and environmental citizenship behavior in both private and public sphere. The detailed results are depicted in Table 6 , and Figure 4 respectively.

By adopting a multi-group approach, we simultaneously reproduced the path differences between two groups and reported results in either situation. The main strength of this technique regards the fact that it can be easily executed with software; hence, it is less time consuming than qualitative approach. On the contrary, this quantitative technique focuses on theory testing rather than on theory generation. Furthermore, it might lead to reductionist explanations. Table 7 summarizes the strengths and weakness of the multigroup approach adopted in this research.

\begin{tabular}{lccccc}
\hline Construct & AC & AR & PN & ECB_PRI & ECB_PUB \\
\hline Awareness of consequences (AC) & 0.740 & & & & \\
Ascription of responsibility (AR) & 0.674 & 0.781 & & & \\
Personal norm (PN) & 0.548 & 0.629 & 0.751 & & \\
ECB Private-sphere (ECB_PRI) & 0.374 & 0.316 & 0.423 & 0.914 & \\
ECB Public-sphere (ECB_PUB) & 0.655 & 0.739 & 0.613 & 0.739 & 0.785 \\
Cronbach's alpha & 0.826 & 0.749 & 0.852 & 0.938 & 0.822 \\
CR & 0.828 & 0.756 & 0.854 & 0.939 & 0.828 \\
AVE & 0.548 & 0.610 & 0.565 & 0.837 & 0.617
\end{tabular}

Notes: $\mathrm{CR}=$ Composite reliability, $\mathrm{AVE}=$ Average variance extracted, Italic values $=\sqrt{A V E}$
Environmental citizenship behavior 


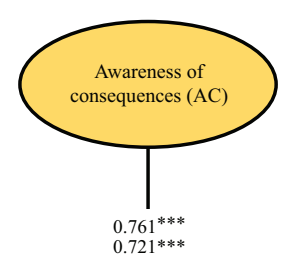

Figure 4.

Results of the multigroup structural equation modeling

Source: Our elaboration

\section{Discussion}

Our findings contribute to the extant literature in several ways. First, this study has shown that norm-activation model is consistent in explaining or predicting environmental citizenship behavior. Second, to the best of our knowledge, this is one of the first study investigating the role of sustainability apps in the relationship between environmental citizenship behavior and some of its predictors, namely, personal norms, ascription of responsibility and awareness of consequences.

Third, through the multi-group analysis, it was found prominent differences between individuals who use sustainability apps and those who do not use sustainability apps. Specifically, sustainability apps utilization strengthen the relationship between ascription of responsibility and personal norm. For example, an app such as AWorld uses stories and information about sustainability to encourage the members to take pro-environmental actions and build a shared sense of purpose. Furthermore, individuals who use sustainability apps are more prone to translate their personal norm into environmental citizen behavior in both private and public setting. Therefore, this study supports the hypothesis regarding the moderating effect of sustainability apps.

Fourth, this research indicated that individuals tend to show their environmental citizenship especially through actions associated with their private-sphere, such as reducing

Table 7.

Strengths and weakness of multigroup analysis 
household energy consumption, recycling and opt for eco-friendly products. One possible reason for this finding may be due to the particular model of environmental education. According to Chawla and Cushing (2007), environmental education focuses principally on the private-sphere environmentalism rather than preparing students for public actions, such as act, protest, lobbing and participation in environmental movements.

The urgency to reimagine and recreate a non-formal as well as formal environmental education for children, youth and older people has been highlighted in a recent paper published by Reid et al. (2021). Specifically, the authors invoke an environmental education

Environmental citizenship behavior grounded on critical thinking, close to science and that enables individuals to identify fake information and ideologies that underestimate the relationship between economic growth and environmental impact.

Another explanation may lie in the fact that sustainability apps, except sporadic cases (Buycott app), are designed to achieve personal sustainability goals. However, as stated by Dobson (2007), private actions have also public implications. For example, our choice to live sustainably allows that others may live well. Furthermore, our actions can inspire other individuals and motivate them to change behavior.

The current study offers to governments and policymakers some practical implications for transforming society through the adoption of ICTs such as sustainability apps. These types of technologies can be used to engage those people who would like to adopt a more sustainable lifestyle but they need a final push. The objective of sustainability app is to trigger behavioral change by means of specific alerting features and gamified scenarios that may be found not to be necessarily cost-effective.

Central governments and cities could develop mobile apps to achieve specific sustainability goals and furnish to citizens personalized services. Furthermore, sustainability apps can be integrated into smart city ecosystems (Kashef et al., 2021; Lytras et al., 2019; Visvizi et al., 2018b; Lytras and Visvizi, 2018; Troisi et al., 2022) to improve pro-environmental activities such as recycling, reduce food waste, donating clothes and sharing stuffs.

As knowledge, skills development and environmental awareness are a prerequisite for environmental citizenship behavior, public and private educational institutions, including universities, can adopt sustainability apps to foster innovative environmental educational approaches that emphasize reflection on direct, concrete experience. Furthermore, sustainability apps favorite value co-creation in educational context (Loia et al., 2016), as well as human connections and a networked learning (Lytras et al., 2018).

\section{Conclusions}

In this paper, we assessed the potentials of sustainability apps to contribute to environmental citizenship behaviors. Hence, the study provides insights about how the adoption of this specific technology, which takes advantage of the ubiquitous of smartphones and other portable devices, may strengthen the relationship between environmental citizenship behavior and its predictors based on the norm-activation model.

This study has some limitations. First, we used MTurk to test the hypothetical model. This crowdsourcing marketplace has a small population. Therefore, this might compromise data quality due to the potential expositions of the worker to previous similar surveys (Chandler et al., 2019). Future research could consider alternative sources for the target audience (e.g. emails, and face-to-face interview).

Second, this study collected data from the USA. Future research should collect and compare data from different countries to enhance the generalizability.

A third limitation regards the SEM analysis. We estimated only the direct effects of awareness of consequences and ascription of responsibility. Additional research could 
consider personal norms as a mediator (De Groot and Steg, 2009), and examine the indirect effects of awareness of consequences and ascription of responsibility on environmental citizenship behavior in both private and public sphere. Moreover, future research could consider introducing in the conceptual model a control variable, such as usage frequency or app category.

Like most research, we derived our conceptual model from the extant literature. The norm-activation model showed consistent findings. However, a plethora of potential constructs, such as values and social norms, may be considered within subsequent work.

\section{References}

Abner, M. and Baytar, F. (2019), "Apps to increase student engagement: a case of textiles and apparel sustainability education", International Journal of Fashion Design, Technology and Education, Vol. 12 No. 1, pp. 56-64.

Aguiar-Castillo, L., Rufo-Torres, J., De Saa-Pérez, P. and Pérez-Jiménez, R. (2018), "How to encourage recycling behaviour? The case of WasteApp: a gamified mobile application”, Sustainability, Vol. 10 No. 5.

Barry, J. (2006), "Resistance is fertile: from environmental to sustainability citizenship", in Dobson, A. and Bell, D. (Eds), Environmental Citizenship, MIT Press, Cambridge, pp. 21-48.

Bauer, N., Megyesi, B., Halbac-Cotoara-Zamfir, R. and Halbac-Cotoara-Zamfir, C. (2020), "Attitudes and environmental citizenship”, in Hadjichambis, A.C., Reis, P., Paraskeva-Hadjichambi, D., Cinčera, J., Boeve-de Pauw, J., Gericke, N. and Knippels, M.C. (Eds), Conceptualizing Environmental Citizenship for 21st Century Education, Springer Nature, Cham, Switzerland, pp. 97-111.

Bell, D. (2005), "Liberal environmental citizenship”, Environmental Politics, Vol. 14 No. 2, pp. 179-194.

Bellamy, R. (2014), “Citizenship: historical development of”, in Wright, J. (Ed.), International Encyclopaedia of Social and Behavioural Sciences, (2nd Ed.), Elsevier, Amsterdam.

Bobeth, S. and Kastner, I. (2020), "Buying an electric car: a rational choice or a norm-directed behavior?", Transportation Research Part F: Traffic Psychology and Behaviour, Vol. 73, pp. 236-258.

Brauer, B. Ebermann, C. Hildebrandt, B. Remané, G. and Kolbe, L.M. (2016), "Green by app: the contribution of mobile applications to environmental sustainability", PACIS 2016 Proceedings, 220, available at: https://aisel.aisnet.org/pacis2016/220

Byrne, B.M. (2004), "Testing for multigroup invariance using AMOS graphics: a road less traveled", Structural Equation Modeling: A Multidisciplinary Journal, Vol. 11 No. 2, pp. 272-300.

Carlo Bertot, J., Jaeger, P.T. and Grimes, J.M. (2012), "Promoting transparency and accountability through ICTs, social media, and collaborative e-government", Transforming Government: People, Process and Policy, Vol. 6 No. 1, pp. 78-91.

Chandler, J., Rosenzweig, C., Moss, A.J., Robinson, J. and Litman, L. (2019), "Online panels in social science research: expanding sampling methods beyond mechanical turk", Behavior Research Methods, Vol. 51 No. 5, pp. 2022-2038.

Chawla, L. and Cushing, D.F. (2007), "Education for strategic environmental behavior", Environmental Education Research, Vol. 13 No. 4, pp. 437-452.

Cohen, M.J. (2020), "Does the COVID-19 outbreak mark the onset of a sustainable consumption transition?", Sustainability: Science, Practice and Policy, Vol. 16 No. 1, pp. 1-3.

De Groot, J.I.M. and Steg, L. (2009), "Morality and prosocial behaviour: the role of awareness, responsibility, and norms in the norm activation model", The Journal of Social Psychology, Vol. 149 No. 4, pp. 425-449.

de Guttry, C., Süsser, D. and Döring, M. (2019), "Situating climate change: psychological distances as tool to understand the multifaceted dimensions of climate change meanings", Geoforum, Vol. 104, pp. 92-100. 
de Vries, G. (2020), "Public communication as a tool to implement environmental policies", Social Issues and Policy Review, Vol. 14 No. 1, pp. 244-272.

Diefenbach, S., Kapsner, A., Laschke, M., Niess, J. and Ullrich, D. (2016), "Technology for behavior change - potential, challenges, and ethical questions", i-com, Vol. 15 No. 2, pp. 195-201.

Environmental citizenship behavior

Dobson, A. (2007), "Environmental citizenship: towards sustainable development", Sustainable Development, Vol. 15 No. 5, pp. 276-285.

Dobson, A. (2010), Environmental Citizenship and Pro-Environmental Behaviour; Rapid Research and Evidence Review, Sustainable Development Research Network, London.

Douglas, B.D. and Brauer, M. (2021), "Gamification to prevent climate change: a review of games and apps for sustainability”, Current Opinion in Psychology, Vol. 42, pp. 89-94.

Eid, R., Selim, H. and El-Kassrawy, Y. (2020), "Understanding citizen intention to use m-government services: an empirical study in the UAE", Transforming Government: People, Process and Policy, Vol. 15 No. 4.

Fornell, C. and Larcker, D.F. (1981), "Evaluating structural equation models with unobservable variables and measurement error", Journal of Marketing Research, Vol. 18 No. 1, pp. 39-50.

Gabrielson, T. (2008), "Green citizenship: a review and critique", Citizenship Studies, Vol. 12 No. 4, pp. $429-446$.

Georges, A., Schuurman, D. and Desmet, M. (2015), "Uncovering the needs and wants of end-users towards green apps: a living lab approach", IEEE International Conference on Engineering, Technology and Innovation/International Technology Management Conference (ICE/ITMC), pp. 1-7.

Georgiou, Y., Hadjichambis, A.C. and Hadjichambi, D. (2021), “Teachers' perceptions on environmental citizenship: a systematic review of the literature", Sustainability, Vol. 13 No. 5, pp. 2622.

Gifford, R. (2011), "The dragons of inaction: psychological barriers that limit climate change mitigation and adaptation", American Psychologist, Vol. 66 No. 4, pp. 290-302.

Gokgoz, Z.A., Ataman, M.B. and van Bruggen, G.H. (2021), "There's an app for that! Understanding the drivers of mobile application downloads", Journal of Business Research, Vol. 123, pp. 423-437.

Hadjichambis, A.C. and Paraskeva-Hadjichambi, D. (2020), "Education for environmental citizenship: the pedagogical approach”, in Hadjichambis, A.C., Reis, P., Paraskeva-Hadjichambi, D., Činčera, J., Boeve-de Pauw, J., Gericke, N. and Knippels, M.C. (Eds), Conceptualizing Environmental Citizenship for 21st Century Education, Springer Nature, Cham, Switzerland, pp. 237-261.

Hadjichambis, A.C. and Reis, P. (2020), "Introduction to the conceptualisation of environmental citizenship for Twenty-First-Century education”, in Hadjichambis, A.C., Reis, P., ParaskevaHadjichambi, D., Činčera, J., Boeve-de Pauw, J., Gericke, N. and Knippels, M.C. (Eds), Conceptualizing Environmental Citizenship for 21st Century Education, Springer Nature, Cham, Switzerland, pp. 1-14.

Hair, J.F., Black, W.C., Babin, B.J., Anderson, R.E. and Tatham, R.L. (2010), Multivariate Data Analysis, (7th ed.), Pearson Prentice Hall, Upper Saddle River, NJ.

Hirsh-Pasek, K., Zosh, J.M., Golinkoff, R.M., Gray, J.H., Robb, M.B. and Kaufman, J. (2015), "Putting education in 'educational' apps: lessons from the science of learning", Psychological Science in the Public Interest, Vol. 16 No. 1, pp. 3-34.

Huang, H. (2016), "Media use, environmental beliefs, self-efficacy, and pro-environmental behavior", Journal of Business Research, Vol. 69 No. 6, pp. 2206-2212.

Jagers, S.C. and Matti, S. (2010), "Ecological citizens: identifying values and beliefs that support individual environmental responsibility among swedes", Sustainability, Vol. 2 No. 4, pp. 1055-1079.

Joanes, T. (2019), "Personal norms in a globalized world: norm-activation processes and reduced clothing consumption”, Journal of Cleaner Production, Vol. 212, pp. 941-949. 
TG

16,2

Johnson, D., Horton, E., Mulcahy, R. and Foth, M. (2017), "Gamification and serious games within the domain of domestic energy consumption: a systematic review", Renewable and Sustainable Energy Reviews, Vol. 73, pp. 249-264.

Kaiser, F.G. and Shimoda, T.A. (1999), "Responsibility as a predictor of ecological behaviour", Journal of Environmental Psychology, Vol. 19 No. 3, pp. 243-253.

Kashef, M., Visvizi, A. and Troisi, O. (2021), "Smart city as a smart service system: human-computer interaction and smart city surveillance systems", Computers in Human Behavior, Vol. 124, pp. $106923 \mathrm{Vol}$

Kline, R.B. (2011), Convergence of Structural Equation Modeling and Multilevel Modeling, SAGE publications, Thousand Oaks, CA.

Kollmuss, A. and Agyeman, J. (2002), "Mind the gap: why do people act environmentally and what are the barriers to pro-environmental behavior?", Environmental Education Research, Vol. 8 No. 3, pp. 239-260.

Laschke, M., Diefenbach, S. and Hassenzahl, M. (2015), 'Annoying, but in a nice way': an inquiry into the experience of frictional feedback”, International Journal of Design, Vol. 9 No. 2, pp. 129-140.

Loia, V., Maione, G., Tommasetti, A., Torre, C., Troisi, O. and Botti, A. (2016), "Toward smart value coeducation", in Uskov, V., Howlett R., Jain, L. (Eds), Smart Education and e-Learning 2016. Smart Innovation, Systems and Technologies, Vol 59, Springer Nature, Cham, Switzerland, pp. 61-71.

Lytras, M.D. and Visvizi, A. (2018), "Who uses smart city services and what to make of it: toward interdisciplinary smart cities research", Sustainability, Vol. 10 No. 6.

Lytras, M.D., Visvizi, A. and Sarirete, A. (2019), "Clustering smart city services: perceptions, expectations, responses", Sustainability, Vol. 11 No. 6.

Lytras, M.D., Visvizi, A., Daniela, L., Sarirete, A. and Ordonez De Pablos, P. (2018), "Social networks research for sustainable smart education”, Sustainability, Vol. 10 No. 9.

Mehra, A., Paul, J. and Kaurav, R.P.S. (2020), "Determinants of mobile apps adoption among young adults: theoretical extension and analysis", Journal of Marketing Communications, pp. 1-29.

Meng, B., Chua, B.L., Ryu, H.B. and Han, H. (2020), "Volunteer tourism (VT) traveler behavior: merging norm activation model and theory of planned behavior", Journal of Sustainable Tourism, Vol. 28 No. 12, pp. 1947-1969.

Milfont, T.L. (2010), "Global warming, climate change and human psychology”, in Corral Verdugo, V., Garcia-Cadana, C.H. and Frias-Arment, M. (Eds), Psychological Approaches to Sustainability: Current Trends in Theory, Practice and Research, Nova Science, Hauppauge (New York, NY), pp. 19-41.

Montiel, I., Delgado-Ceballos, J. and Ortiz-de-Mandojana, N. (2017), "Mobile apps for sustainability management education: the example of GoodGuide, (http://www.goodguide.com/about/mobile)", Academy of Management Learning and Education, Vol. 16 No. 3, pp. 489-493.

Moussaoui, L.S. and Desrichard, O. (2016), “Act local but don't think too global: the impact of ecological goal level on behavior", The Journal of Social Psychology, Vol. 156 No. 5, pp. 536-552.

Mulcahy, R., Russell-Bennett, R. and Iacobucci, D. (2020), "Designing gamified apps for sustainable consumption: a field study", Journal of Business Research, Vol. 106, pp. 377-387.

Nghiem, T.P.L. and Carrasco, L.R. (2016), "Mobile applications to link sustainable consumption with impacts on the environment and biodiversity", BioScience, Vol. 66 No. 5, pp. 384-392.

Ockwell, D., Whitmarsh, L. and O’Neill, S. (2009), "Reorienting climate change communication for effective mitigation: forcing people to be green or fostering grass-roots engagement?", Science Communication, Vol. 30 No. 3, pp. 305-327.

Oni, A.A., Ayo, C.K., Oni, S. and Mbarika, V.W. (2016), "Strategic framework for e-democracy development and sustainability", Transforming Government: People, Process and Policy, Vol. 10 No. 3, pp. 457-477. 
Onwezen, M.C., Antonides, G. and Bartels, J. (2013), "The norm activation model: an exploration of the functions of anticipated pride and guilt in pro-environmental behaviour", Journal of Economic Psychology, Vol. 39, pp. 141-153.

Ouariachi, T., Li, C.Y. and Elving, W.J. (2020), “Gamification approaches for education and engagement on pro-environmental behaviors: searching for best practices", Sustainability, Vol. 12 No. 11, pp. 4565.

Pai, R.R. and Alathur, S. (2019), "Determinants of individuals' intention to use mobile health: insights from India”, Transforming Government: People, Process and Policy, Vol. 13 Nos 3/4, pp. 306-326.

Polese, F., Ciasullo, M.V., Troisi, O. and Maione, G. (2019), "Sustainability in footwear industry: a big data analysis", Sinergie Italian Journal of Management, Vol. 37 No. 1, pp. 149-170.

Reddick, C.G. and Zheng, Y. (2017), "Determinants of citizens' mobile apps future use in chinese local governments: an analysis of survey data", Transforming Government: people, Process and Policy, Vol. 11 No. 2, pp. 213-235.

Reid, A., Dillon, J., Ardoin, N. and Ferreira, J.A. (2021), “Scientists' warnings and the need to reimagine, recreate, and restore environmental education", Environmental Education Research, Vol. 27 No. 6, pp. 783-795.

Roux, D. and Izberk-Bilgin, E. (2018), "Consumer resistance and power relationship in the marketplace", in Arnould, E. and Thompson, C. (Eds), Consumer Culture Theory, SAGE publications, Thousand Oaks, CA, pp. 295-317.

Schwartz, S.H. (1977), "Normative influence on altruism”, Advances in Experimental Social Psychology, Vol. 10, pp. 221-279.

Schwartz, S.H. and Howard, J.A. (1981), "A normative decision making model of altruism”, in Rushton, J.P. and Sorrentino R.M. (Eds), Altruism and Helping Behavior, Lawrence Erlbaum Associates, Hillsdale, NJ, pp. 89-211.

Shank, D.B. (2016), "Using crowdsourcing websites for sociological research: the case of amazon mechanical turk", The American Sociologist, Vol. 47 No. 1, pp. 47-55.

Smederevac-Lalic, M., Finger, D., Kovách, I., Lenhardt, M., Petrovic, J., Djikanovic, V., ... (2020), and Boeve-de Pauw, J. "Knowledge and environmental citizenship", in Hadjichambis, A.C., Reis, P., Paraskeva-Hadjichambi, D., Cinčera, J., Boeve-de Pauw, J., Gericke, N. and Knippels, M.C. (Eds), Conceptualizing Environmental Citizenship for 21st Century Education, Springer Nature, Cham, Switzerland, pp. 69-82.

Stern, P.C. (2011), "Contributions of psychology to limiting climate change", American Psychologist, Vol. 66 No. 4, pp. 303-314.

Stern, P.C., Dietz, T., Abel, T., Guagnano, G.A. and Kalof, L. (1999), "A value-belief-norm theory of support for social movements: the case of environmentalism", Human Ecology Review, Vol. 6 No. 2, pp. 81-97.

Thøgersen, J. (2006), "Norms for environmentally responsible behaviour: an extended taxonomy", Journal of Environmental Psychology, Vol. 26 No. 4, pp. 247-261.

Troisi, O., Visvizi, A. and Grimaldi, M. (2021), "The different shades of innovation emergence in smart service systems: the case of Italian cluster for aerospace technology", Journal of Business and Industrial Marketing, Vol. 1.

Troisi, O., Grimaldi, M., Loia, F. and Maione, G. (2018), "Big data and sentiment analysis to highlight decision behaviours: a case study for student population", Behaviour and Information Technology, Vol. 37 No. 10-11, pp. 1111-1128.

Troisi, O., Fenza, G., Grimaldi, M. and Loia, F. (2022), "Covid-19 sentiments in smart cities: the role of technology anxiety before and during the pandemic", Computers in Human Behavior, Vol. 126.

United Nations (1987), "Report of the world commission on environment and development: Our common future", available at: https:/sustainabledevelopment.un.org/content/documents/ 5987our-common-future.pdf (accessed 22 June 2021). 
Verplanken, B. and Roy, D. (2016), "Empowering interventions to promote sustainable lifestyles: testing the habit discontinuity hypothesis in a field experiment", Journal of Environmental Psychology, Vol. 45, pp. 127-134.

Visvizi, A., Lytras, M.D. and Daniela, L. (2018a), "Education, innovation and the prospect of sustainable growth and development", in Visvizi, A., Lytras, M.D. and Daniela, L. (Eds), The Future of Innovation and Technology in Education: Policies and Practices for Teaching and Learning Excellence (Emerald Studies in Higher Education, Innovation and Technology), Emerald Publishing Limited, Bingley, pp. 297-305.

Visvizi, A., Lytras, M.D., Damiani, E. and Mathkour, H. (2018b), "Policy making for smart cities: Innovation and social inclusive economic growth for sustainability", Journal of Science and Technology Policy Management, Vol. 9 No. 2, pp. 126-133.

Wang, S., Leviston, Z., Hurlstone, M., Lawrence, C. and Walker, I. (2018), "Emotions predict policy support: why it matters how people feel about climate change", Global Environmental Change, Vol. 50, pp. 25-40.

Whittaker, L., Mulcahy, R. and Russell-Bennett, R. (2021), 'Go with the flow' for gamification and sustainability marketing", International Journal of Information Management, Vol. 61.

Yanamandra, R. and Ramesh, A. (2019), "Motivating the stakeholders through a contest based mobile application for promoting and rewarding sustainability initiatives", Skyline Business Journal, Vol. 15 No. 2, pp. 30-40.

Yang, X., Chen, S.C. and Zhang, L. (2020), "Promoting sustainable development: a research on residents' green purchasing behavior from a perspective of the goal-framing theory", Sustainable Development, Vol. 28 No. 5, pp. 1208-1219.

Zhang, X., Liu, J. and Zhao, K. (2018), “Antecedents of citizens' environmental complaint intention in China: an empirical study based on norm activation model", Resources, Conservation and Recycling, Vol. 134, pp. 121-128.

Zhang, Y., Wang, Z. and Zhou, G. (2013), "Antecedents of employee electricity saving behavior in organizations: an empirical study based on norm activation model", Energy Policy, Vol. 62, pp. 1120-1127.

\section{Further reading}

Hair, J.F., Jr, Sarstedt, M., Hopkins, L. and Kuppelwieser, V.G. (2014), "Partial least squares structural equation modeling (PLS-SEM): an emerging tool in business research", European Business Review, Vol. 26 No. 2, pp. 106-121.

Trope, Y. and Liberman, N. (2010), "Construal-level theory of psychological distance", Psychological Review, Vol. 117 No. 2, pp. 440-463.

\section{Corresponding author}

Mario D'Arco can be contacted at: mdarco@unisa.it

For instructions on how to order reprints of this article, please visit our website: 